\title{
Status of the Golden Eagle Aquila chrysaetos in Europe
}

\author{
J. WATSON
}

\begin{abstract}
Summary
Population estimates (number of breeding pairs) of Golden Eagles Aquila chrysaetos are given for most countries in Europe based on recent published accounts. Where published data are not available information is from local raptor specialists. The "best estimate" of the contemporary European population is 5,600 pairs $\pm 5 \%$. The largest numbers are in Spain (c. 1,200 pairs) with Norway, European Russia, Scotland and Sweden each holding over 300 pairs. Information on trends reveals that most substantial populations $(>200$ pairs) are stable; decreases are reported from some Baltic countries and in parts of southeast Europe. The total population is also shown for five biogeographic regions across Europe. In some cases, such "regions" may be more appropriate for the formulation of conservation priorities and policies than are the biologically artificial units defined by national boundaries.
\end{abstract}

Des estimations des populations (nombre de couples nicheurs) d'Aigles royaux basées sur des publications récentes sont présentées pour la plupart des pays d'Europe. Là où les publications font défaut, des informations ont été requises apurès de spécialistes locaux. La population européene actuelle est estimée à 5,600 couples $\pm 5 \%$. Les populations les plus fortes, soit plus de 300 couples, se trouvent en Espagne (env. 1,200 couples), Norvège, Russie européene, Ecosse et Suède. Les informations sur les tendances des fluctuations indiquent que la plupart des grandes populations (plus de 200 couples) sont stables; un déclin a été constaté chez certaines populations de l'est de la Baltique et du sudest de l'Europe. La population totale est aussi indiquée pour cinq régions biogéographiques qui peuvent s'avérer plus adéquates que les pays avec leurs frontières artificielles pour la formulation de priorités et d'une politique pour la conservation de l'espèce.

\section{Introduction}

Population estimates of uncommon species such as diurnal raptors are increasingly being used to support national and international conservation and protection policies (Bezzel 1980, Stroud et al. 1990). For example, the European Communities Birds Directive (79/409/EEC) requires member states to enact "special conservation measures" for a list of species (Annex 1 in the Directive). The Directive goes on to say that "Trends and variations in population levels shall be taken into account as a background for evaluations" and further "that Member States shall classify ... special protection areas for the conservation of these species". If this policy is to retain political and biological credibility it is important that the information which underpins it is widely available and is periodically reviewed in the light of new research and survey. This paper presents a 
comprehensive review of the status of one such Annex 1 species, the Golden Eagle Aquila chrysaetos, throughout Europe west of the Urals. It builds on a series of earlier reviews, most of which were geographically incomplete (Bijleveld 1974, Chancellor 1977, Cramp and Simmons 1980, Dennis et al. 1984, Génsbøl 1987, Meyburg and Meyburg 1987, Michel 1987) and incorporates the most contemporary published and unpublished population estimates for the species available at the end of 1991.

\section{Sources of information}

Where possible, information was obtained by extensive review of the European literature although, for the majority of countries, a population estimate for Golden Eagles was published during the period 1984-1991. If gaps were evident I wrote to known authorities on diurnal raptors and replies were received in most cases. Full details of sources are given under each country in the geographical review. In all cases the population estimate is for the number of breeding pairs of Golden Eagles.

\section{Scope of the review}

Europe is defined as those countries north of the Mediterranean (including the islands) and west of the Ural mountains. The south-eastern boundary is taken arbitrarily as a line from Orsk $\left(51^{\circ} 12^{\prime} \mathrm{N} 58^{\circ} 34^{\prime} \mathrm{E}\right)$ south-westwards to Odessa $\left(46^{\circ} 28^{\prime} \mathrm{N} 30^{\circ} 44^{\prime} \mathrm{E}\right)$ on the Black Sea. Turkey, the Middle East and North Africa are therefore excluded from the assessment although they fall within the western Palearctic biogeographic region. Knowledge of the status of Golden Eagles in these countries is generally poor.

In most cases information is presented by country and separately for the recently independent states of the former USSR. The main exceptions are the larger Mediterranean islands (Corsica, Sardinia, Sicily and Crete), which are geographically distinct from their respective geopolitical affiliations and are therefore dealt with as separate units.

\section{Geographical review}

The following country/island accounts are listed in alphabetical order and summary information on status is presented in Table 1 . The trend in the population is given in one of four categories (increasing, decreasing, stable, unknown) and the source is the same as the population estimate unless otherwise stated. Whilst some figures clearly exhibit spurious accuracy I have not attempted to change these from figures given by the original authors.

1. Albania. Ornithologically this is one of the least known countries in Europe and the estimate of $40^{-}-50$ pairs by Mevlan and Jaupi in Michel (1987) is the best available. Trend Unknown.

2. Austria. Niederwolfsgruber (1987) gives a minimum estimate of $60-70$ pairs, with a possible additional 20-30 breeding pairs. However, Gamauf (1991) gives 
Table 1. Population estimates of Golden Eagles and current trends in 26 European countries and five of the larger Mediterranean islands.

\begin{tabular}{|c|c|c|}
\hline Location & $\begin{array}{c}\text { Estimated population } \\
\text { size (breeding pairs) }\end{array}$ & Trend $^{\mathrm{a}}$ \\
\hline 1. Albania & $40-50$ & $U$ \\
\hline 2. Austria & $60-250$ & $\mathrm{~S}$ \\
\hline 3. Belorussia & $30-40$ & $\mathrm{D}$ \\
\hline 4. Bulgaria & $130-140$ & $\mathrm{U}$ \\
\hline 5. Corsica & $29-35$ & $\mathrm{~S}$ \\
\hline 6. Crete & 10 & $\mathrm{U}$ \\
\hline 7. Cyprus & 2 & $\mathrm{U}$ \\
\hline 8. Czechoslovakia & $60-70$ & $\mathbf{S}$ \\
\hline 9. England & $1-2$ & S \\
\hline 10. Estonia & $25-30$ & $\mathrm{~s}$ \\
\hline 11. Finland & 220 & I \\
\hline 12. France ${ }^{b}$ & 250 & $\mathrm{~S}$ \\
\hline 13. Germany & $25-30$ & $\mathbf{S}$ \\
\hline 14. Greece $c^{c}$ & 210 & $\mathrm{D}$ \\
\hline 15. Hungary & 1 & $\mathrm{U}$ \\
\hline 16. Italy ${ }^{d}$ & $250-339$ & $\mathrm{U}$ \\
\hline 17. Latvia & 10 & $\mathrm{U}$ \\
\hline 18. Lithuania & ? few & $\mathrm{U}$ \\
\hline 19. Norway & $700-1,000$ & $\mathrm{~s}$ \\
\hline 20. Poland & 15 & D \\
\hline 21. Portugal & $15-20$ & D \\
\hline 22. Romania & $28-30$ & $\mathrm{~S}$ \\
\hline 23. Russia (part) & $300-700$ & $\mathrm{U}$ \\
\hline 24. Sardinia & $30-38$ & $\mathrm{U}$ \\
\hline 25. Scotland & $420-425$ & $\mathrm{~S}$ \\
\hline 26. Sicily & 13 & $\mathrm{D}$ \\
\hline 27. Spain & $1,192-1,265$ & $\mathrm{~S}$ \\
\hline 28. Sweden & 600 & $\mathrm{~S}$ \\
\hline 29. Switzerland & $200-250$ & S \\
\hline 30. Ukraine & $5-6$ & $\mathrm{U}$ \\
\hline 31. Yugoslavia & 100 & D \\
\hline Total & $4,971-6,151$ & \\
\hline
\end{tabular}

aS, stable; I, increasing; D, decreasing; U, unknown.

'Excluding Corsica; 'Excluding Crete; ${ }^{\mathrm{d}}$ Excluding Sardinia and Sicily.

200-250 pairs. The figure in Table 1 gives the minimum-maximum range based on the above. Trend Stable.

3. Belorussia. V. V. Ivanovsky (in litt.) reports a population of 30-40 pairs in 1990. Trend probably Decreasing.

4. Bulgaria. A recent and extensive survey revealed an estimated 130-140 pairs (Michev et al. 1989). Trend Unknown.

5. Corsica. A report of 16 pairs in 1977 (Thibault in Génsbol 1987) has been revised upwards to $29-35$ pairs, following fuller investigation (J.-C. Thibault verbally 1992). Trend Stable.

6. Crete. Vagliano (1981) estimates 10 pairs on Crete. Trend Unknown.

7. Cyprus. Meyburg and Meyburg (1987) report just two pairs. Trend Unknown.

8. Czechoslovakia. S. Danko (in litt.) states that the present population (1991) numbers some 60-70 pairs, all in Slovakia. Trend Stable. 
9. England. Over the ten years 1981-1990 the population in England has been 1 or 2 pairs (RSPB unpublished data). Trend probably Stable.

10. Estonia. T. E. Randla (in litt.) estimates the population in 1990 as 25-30 pairs. Trend probably Stable.

11. Finland. S. Sulkava (in litt.) and Virolainen and Rassi (1990) report a Finnish population of 220 pairs. Trend Increasing slowly.

12. France. The published estimate of 250 pairs (Meyburg and Meyburg 1987) was quickly superseded by a revised estimate by Michel (1987) of 280 pairs. The figure in Table 1 has been calculated by removing an estimated 30 pairs for Corsica, leaving 250 pairs for mainland France. Trend probably Stable.

13. Germany. The most recent published estimate is Bezzel and Schöpf (1987) with 25-30 pairs, all in southern Bavaria. Trend Stable.

14. Greece. Excluding Crete there are an estimated 210 pairs (Meyburg and Meyburg 1987), although Andrinos (1987) gives a lower figure of 150-200 for the whole of Greece. Trend probably Decreasing (Hallman 1985).

15. Hungary. The first contemporary record of breeding in Hungary was in 1987 (Anon. 1988). Trend Unknown.

16. Italy. The best estimate is given by Fasce and Fasce (1987) with 250-339 pairs and some $50-60$ of these in the Appennines, the remainder in the Italian Alps. Estimates for Sicily and Sardinia have been excluded. Trend Unknown.

17. Latvia. An estimate of 10 pairs is given by T. E. Randla (in litt.). Trend Unknown.

18. Lithuania. According to T. E. Randla (in litt.) "some pairs may occur", although there are no confirmed breeding records for recent years. Trend Unknown.

19. Norway. Bergo (1987) summarizes recent estimates and concludes with a figure of 500 pairs. However, Gjershaug (1991) revises this upwards to $700-1,000$ pairs. Trend Stable.

20. Poland. Krol (1987) estimates some 15 pairs, mainly in the extreme south-east and extreme north-east of the country. Trend Decreasing.

21. Portugal. Rufino et al. (1985) estimate 15-20 pairs for 1982. Trend probably Decreasing (Palma 1985).

22. Romania. L. Kalaber (in litt.) gives an estimate of 28-30 pairs for 1990. Trend Stable.

23. Russia. For European Russia, west of the Urals, T. E. Randla (in litt.) estimates some 600-700 pairs, although Galushin (in press) gives 300 pairs only. The figure in Table 1 gives the minimum-maximum range based on the above. Trend Unknown.

24. Sardinia. There are some $30-38$ pairs (Fasce and Fasce 1987). Trend Unknown.

25. Scotland. The national survey in 1982-1983 revealed some 420-425 pairs (Dennis et al. 1984). Trend probably Stable.

26. Sicily. An estimated 13 pairs breed (Seminara et al. 1987). Trend probably Decreasing.

27. Spain. Arroyo et al. (1990) published the results of a national survey done mainly in 1987-1988. They estimate the Spanish population to be between 1,192 and 1,265 pairs. Trend Stable.

28. Sweden. Tjernberg (1990) estimates the population to be around 600 pairs.

Trend Stable. 
29. Switzerland. Extrapolating from detailed census work in parts of Switzerland the whole population is estimated at 200-250 pairs (Haller 1987). Trend Stable. 30. Ukraine. Gorban (1985) estimates 5 or 6 pairs for the Ukraine. Trend Unknown.

31. Yugoslavia. Vasić et al. (1985) estimate 100 pairs for Yugoslavia with the largest proportion in Macedonia. Trend slowly Decreasing.

\section{Size of the European population}

Based on the figures in Table 1 , an estimate of the contemporary population of Golden Eagles in Europe would lie in the range 4,971-6,151 pairs. Removing the spurious accuracy of these figures it is probable that the best estimate is somewhere in the range $5,600 \pm 5 \%$. Since figures for virtually all countries with estimated populations larger than 200 pairs have now been derived from complete or partial census data it is unlikely that the true figure will differ substantially from this estimate. Probably the greatest uncertainty lies in countries with populations in the range 50-100 pairs (e.g. Albania, Austria, Yugoslavia) where census data are few. Judging by the estimated population in surrounding countries, the figure for Romania may well be low. In countries where partial or complete censuses have recently been taken for the first time (for Spain, Arroyo et al. 1990; for Scotland, Dennis et al. 1984; for Sweden, Tjernberg 1990) the result has invariably been to raise substantially the previous "best estimate". It is therefore extremely unlikely that, when better data are available for less well known countries, the final figure for Europe will be lower than the current "best estimate".

\section{Trends in populations}

Information on trends is generally encouraging. Whilst in only $14(45 \%)$ of the 31 units populations are considered stable or increasing, these in fact account for nearly $70 \%$ of the total estimated population. The main areas where a decrease is reported are in the regions termed below as the Balkan Mountains (particularly Greece and Yugoslavia) and the East Baltic Lowlands (particularly Poland and Belorussia). In Greece and Yugoslavia as well as Sicily and Portugal, the principal reasons for declines have been human persecution and disturbance, whilst habitat destruction, mainly loss of wooded peatlands, is the main cause in Poland and Belorussia. Of these populations where the trend is unknown it is likely that the large Russian population may be subject to habitat loss comparable to that in Poland and Belorussia. It is also possible, given the trends in surrounding countries, that threats from persecution may be impinging on populations in Italy, Albania and Bulgaria.

\section{Biogeographic regions}

Estimates of population size have inevitably been derived from survey work done, and knowledge accumulated, within geopolitical units (mainly countries). However, these essentially artificial divisions may not be the most appropriate units within which to judge the general health and conservation needs of wide- 
ranging, low-density species such as Golden Eagles. Instead such birds lend themselves to a more radical approach based on biogeographic regions, and this is particularly appropriate when information on distribution and abundance is relatively complete over an area as large as Europe. For the Golden Eagle the various country populations fall into five clear biogeographic regions (Watson 1991): the North-West Mountains, East Baltic Lowlands, West Mediterranean Mountains, Alpine Mountains and Balkan Mountains (Figure 1 and Table 2). A comparison of Table 2 with the trends column in Table 1 shows clearly the priority areas for conservation action if Golden Eagles are to be retained over their full range across Europe. Populations in the North-West Mountains and the West Mediterranean Mountains are large and generally stable and that in the Alpine Mountains, though smaller, is clearly healthy. However, the smaller populations in the East Baltic Lowlands and the Balkan Mountains are under threat with population declines identified in several countries. Retention of a substantial population of the remarkable lowland-bog-nesting eagles (Zastrov 1946) will depend on effective conservation of their habitat in European Russia and Finland. By contrast, control of persecution through effective legislation and conservation education should be sufficient to reverse apparent declines in the Balkan Mountains.

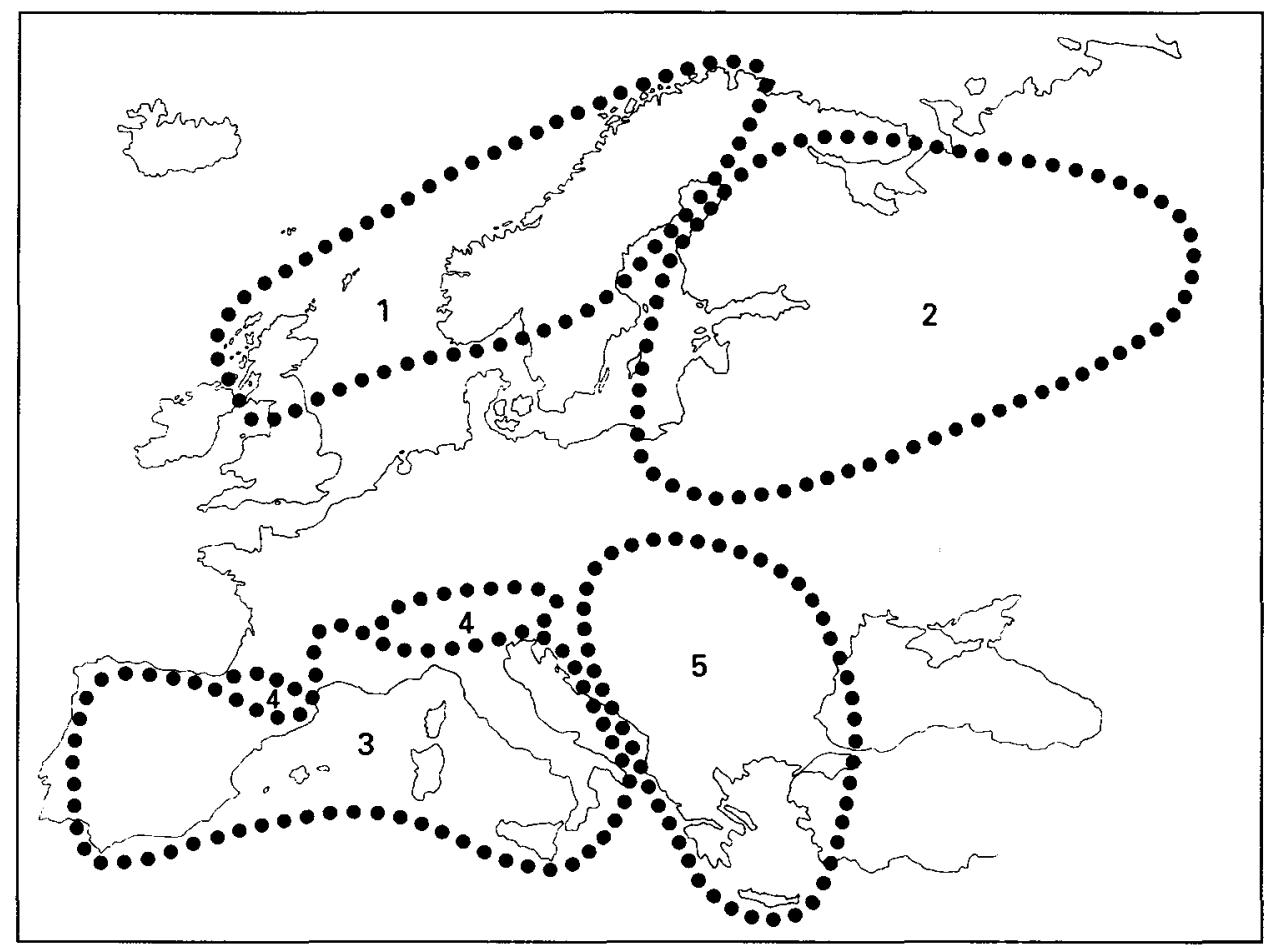

Figure 1. Map of Europe showing the approximate locations of the five biogeographic regions referred to in the text. The regions are 1, North-West Mountains; 2, East Baltic Lowlands; 3, West Mediterranean Mountains; 4, Alpine Mountains; 5, Balkan Mountains. 
Table 2. Population estimates of Golden Eagles in five biogeographic regions across Europe. Locations falling within regions are listed (see text for details) along with a brief description of ecological features.

\begin{tabular}{|c|c|c|c|}
\hline $\begin{array}{l}\text { Biogeographic } \\
\text { regions }\end{array}$ & $\begin{array}{l}\text { Locations a falling } \\
\text { within each } \\
\text { biogeographic } \\
\text { region }\end{array}$ & $\begin{array}{l}\text { Ecological features }{ }^{b} \text { of } \\
\text { region as reflected by } \\
\text { Golden Eagle } \\
\text { populations }\end{array}$ & $\begin{array}{l}\text { Total } \\
\text { estimated } \\
\text { population } \\
\text { of each } \\
\text { region }^{c}\end{array}$ \\
\hline North-West Mountains & $9,19,25,28$ & $\begin{array}{l}\text { Nesting at or above treeline, } \\
\text { on cliffs or trees; main food } \\
\text { grouse (Tetraonidae) and } \\
\text { hares/rabbits (Leporidae) }\end{array}$ & 1,880 \\
\hline East Baltic Lowlands & $\begin{array}{c}3,10,11,17,18 \\
20,23\end{array}$ & $\begin{array}{l}\text { Only strictly lowland ( }<200 \mathrm{~m} \\
\text { asl) population in Europe; } \\
\text { exclusively tree-nesting. Food } \\
\text { mainly avian and very varied }\end{array}$ & 810 \\
\hline $\begin{array}{l}\text { West Mediterranean } \\
\text { Mountains }\end{array}$ & $\begin{array}{c}5,12 \text { (part), } 16 \text { (part), } \\
21,24,26,27 \text { (part) }\end{array}$ & $\begin{array}{l}\text { Nesting below treeline in arid } \\
\text { landscape mainly on cliffs. } \\
\text { Main food is partridge } \\
\text { (Alectoris) and hare (Lepus) }\end{array}$ & 1,470 \\
\hline $\begin{array}{l}\text { Alpine }^{\mathrm{d}} \\
\text { Mountains }\end{array}$ & $\begin{array}{c}2,12 \text { (part), 13, } 16 \\
\text { (part), } 27 \text { (part), } 29\end{array}$ & $\begin{array}{l}\text { Nesting in cliffs at high } \\
\text { altitude; generally hunting } \\
\text { above natural treeline. Food } \\
\text { usually includes high \% of } \\
\text { marmots (Marmota) }\end{array}$ & 840 \\
\hline \multirow[t]{2}{*}{$\begin{array}{l}\text { Balkan } \\
\text { Mountains }\end{array}$} & $\begin{array}{c}1,4,6,7,8 \\
14,15 \\
22,30 \\
31\end{array}$ & $\begin{array}{c}\text { Mainly cliff-nesting; hunting } \\
\text { below natural treeline. } \\
\text { Tortoises (Testudinidae) } \\
\text { usually form high \% of diet }\end{array}$ & 600 \\
\hline & & Total & 5,600 \\
\hline
\end{tabular}

a Numbers refer to locations given in the Geographical Review and Table 1.

b These are aspects of nest site selection, hunting terrain and diet and have been chosen to represent some of the ecological differences between regions. Information is mainly from Cramp and Simmons (1980) but also several of the regional accounts referred to in this paper; see also Watson (1991).

c These figures have been rounded to the nearest 10.

d Includes the high mountains of the Alps and the Pyrenees.

Whilst the implementation of conservation policies will probably always be determined by national governments, it is helpful for the formulation of conservation priorities to view biological information in its true biogeographical context. For example, the Scottish population of Golden Eagles comprises some $7.5 \%$ of the European population but over $22 \%$ of the population in the NorthWest Mountains biogeographical region. This clearly places an international obligation on the British government in relation to the conservation of Golden Eagles. By contrast, the population in Portugal is just $0.3 \%$ of the European and $1.2 \%$ of the West Mediterranean population. The international obligation is clearly less, though the fact that the population is apparently decreasing should be a factor in determining national priorities for bird conservation in Portugal. 


\section{Acknowledgements}

I am indebted to S. Danko, V. V. Ivanovsky, L. Kalabar, T. E. Randla and J.-C. Thibault for providing me with unpublished information on Golden Eagle status in their countries and to B. Arroyo, J. Gjershaug, T. Michev, S. Sulkava and G. Tucker for sending me important recent publications. Sandy Payne and Ro Scott criticized an earlier draft and Ian Sarjeant drew the figure. J.-P. Biber translated the summary into French.

\section{References}

Andrinos, G. E. (1987) L'Aigle royal en Grèce. Pp.18-22 in S. Michel, ed. L'Aigle royal en Europe. Actes du Premier colloque international sur l'Aigle royal en Europe. Arvieux. Anon. (1988) European news. Brit. Birds 81: 16.

Arroyo, B., Ferreiro, E. and Garza, V. (1990) El Aguila Real (Aquila chrysaetos) en España: censo, distribución, reproducción y conservación. Madrid: ICONA.

Bergo, G. (1987) L'Aigle royal en Norvège. Pp.40-42 in S. Michel, ed. L'Aigle royal en Europe. Actes du Premier colloque international sur l'Aigle royal en Europe. Arvieux.

Bezzel, E. (1980) An assessment of the endangered status of Europe's breeding birds and the importance of their biotopes as a basis for protective measures. Brussels: Report (DOC.ENV/22/80) to the European Commission.

Bezzel, E. and Schöpf, H. (1987) L'Aigle royal en R.F.A. Pp.48-49 in S. Michel, ed. L'Aigle royal en Europe. Actes du Premier colloque international sur l'Aigle royal en Europe. Arvieux.

Bijleveld, M. (1974) Birds of prey in Europe. London: Macmillan.

Chancellor, R. D., ed. (1977) World conference on birds of prey: report of proceedings, Vienna 1975. London: International Council for Bird Preservation.

Cramp, S. and Simmons, K. E. L., eds. (1980) The birds of the western Palearctic, 2: hawks to bustards. Oxford: Oxford University Press.

Dennis, R. H., Ellis, P. M., Broad, R. A. and Langslow, D. R. (1984) The status of the Golden Eagle in Britain. Brit. Birds 77: 592-607.

Fasce, P. and Fasce, L. (1987) L'Aigle royal en Italie. Pp. 23-28 in S. Michel, ed. L'Aigle royal en Europe. Actes du Premier colloque international sur l'Aigle royal en Europe. Arvieux.

Galushin, V. M. (in press) Long-standing changes in birds of prey populations within European Russia and neighbouring countries. Paper presented to 12 th International Conference of International Bird Census Committee and European Ornithological Atlas Committee.

Gamauf, A. (1991) Greifvögel in Österreich: Populationen, Gefähren, Gesetzen. Monogr. Umweltbundesantes 29.

Génsbøl, B. (1987) Birds of prey of Britain and Europe. London: Collins.

Gjershaug, J. (1991) Rovfugler. P.191 in O. Hogstad, ed. Norges Dyr. Fuglene, 1. Oslo: J. W. Cappelens Forlag.

Gorban, I, . (1985) Current status of eagles in the Western Ukraine, USSR. WWGBP Bull. 2: 28-29.

Haller, H. (1987) L'Aigle royal en Suisse. Pp.52-53 in S. Michel, ed. L'Aigle royal en Europe. Actes du Premier colloque international sur l'Aigle royal en Europe. Arvieux.

Hallmann, B. (1985) Status and conservation problems of birds of prey in Greece. Pp.5559 in I. Newton and R. D. Chancellor, eds. Conservation studies on raptors. Cambridge, U.K.: International Council for Bird Preservation (Techn. Publ. 5).

Krol, W. (1987) L'Aigle royal en Pologne. Pp.43-47 in S. Michel, ed. L'Aigle royal en Europe. Actes du Premier colloque international sur l'Aigle royal en Europe. Arvieux.

Meyburg, B.-U. and Meyburg, C. (1987) Present status of diurnal birds of prey (Falconi- 
formes) in various countries bordering the Mediterranean. Ric. Biol. Selvaggina 12: 147-152.

Michel, S. (1987) Estimation du nombre de couples d'Aigles royaux en Europe. P.165 in S. Michel, ed. L'Aigle royal en Europe. Actes du Premier colloque international sur l'Aigle royal en Europe. Arvieux.

Michev, T., Petrov, T., Profirov, L., Yankov, P. and Gavrailov, S. (1989) Distribution and protection status of the golden eagle Aquila chrysaetos chrysaetos (L.), 1758 in Bulgaria. Bull. Mus. South Bulgaria 25: 79-87. (In Russian).

Niederwolfsgruber, F. (1987) L'Aigle royal en Autriche. Pp.11-12 in S. Michel, ed. L'Aigle royal en Europe. Actes du Premier colloque international sur l'Aigle royal en Europe. Arvieux.

Palma, L. (1985) The present situation of birds of prey in Portugal. Pp.3-14 in I. Newton and R. D. Chancellor, eds. Conservation studies on raptors. Cambridge, U.K.: International Council for Bird Preservation (Techn. Publ. 5).

Rufino, R., Araújo, A. and Abreu, M. V. (1985) Breeding raptors in Portugal: distribution and population estimates. Pp.15-28 in I. Newton and R. D. Chancellor, eds. Conservation studies on raptors. Cambridge, U.K.: International Council for Bird Preservation (Techn. Publ. 5).

Seminara, S., Giarratana, S. and Favara, R. (1987) L'Aigle royal en Sicile. Pp.33-36 in S. Michel, ed. L'Aigle royal en Europe. Actes du Premier colloque international sur l'Aigle royal en Europe. Arvieux.

Stroud, D. A., Mudge, G. P. and Pienkowski, M. W. (1990) Protecting internationally important bird sites. Peterborough: Nature Conservancy Council.

Tjernberg, M. (1990) Kungsörnen Aquila chrysaetos i Sverige - utbreding, status och hot. Vår Fågelvärld 49: 339-348.

Vagliano, C. (1981) Contributions au statut des rapaces diurnes et nocturnes nicheurs en Crete. Pp.14-16 in Rapaces Méditerranéens. Ann. C.R.O.P.

Vasić, V., Grubač, B., Sušić, G. and Marinković, S. (1985) The status of birds of prey in Yugoslavia, with particular reference to Macedonia. Pp.45-53 in I. Newton and R. D. Chancellor, eds. Conservation studies on raptors. Cambridge, U.K.: International Council for Bird Preservation (Techn. Publ. 5).

Virolainen, E. and Rassi, P. (1990) Suomen maakotkakannan kehitys 1970-1980 luvuilla. Lintumies 25: 59-65.

Watson, J. (1991) The golden eagle and pastoralism across Europe. Pp.56-57 in D. J. Curtis, E. M. Bignal and M. A. Curtis, eds. Birds and pastoral agriculture in Europe. Peterborough: Joint Nature Conservation Committee.

Zastrov, M. (1946) Om kungsörnens (Aquila chrysaetos) ut bredning och biologi i Estland. Vår Fågelvärld 5: 64-80.

\section{J. WATSON}

Scotish Natural Heritage, 9 Culduthel Road, Inverness, Scotland, IV2 4 AG, U.K. 